\title{
Improving the Examination System of Medical Non-Degree Courses and Enhancing the Innovative Ability of Postgraduate Students
}

\author{
Jian-gang WANG and Leng-xin DUAN \\ Medical College, Henan University of Science and Technology, Kaiyuan Avenue 263, Luoyang \\ 471023, Henan Province, China
}

Keywords: Examination system, Non-degree courses, Innovative ability.

\begin{abstract}
The improvement of the non-degree curriculum assessment system is conducive to the standardization of the teaching behavior of the teachers, which is beneficial to the cultivation of the postgraduate students' creative ability, and which is beneficial to the correct evaluation of the postgraduate students' academic level. The non-degree courses are divided into three categories, such as the professional knowledge class, the subject progress class and the scientific research skill class. Through the implementation, the innovative consciousness and the innovation ability of the graduate students are preliminarily improved, and the aim of objective evaluation can be achieved.
\end{abstract}

\section{Introduction}

In the curriculum of postgraduate training in our country, degree courses refer to the courses of basic theory and professional knowledge, and non-degree courses refer to professional elective courses, including experimental skills training courses selected according to research directions and frontiers knowledge courses, research design and thesis writing skills courses, etc. Degree courses can train the basic abilities of graduate students, while non-degree courses develop graduate research skills and innovative abilities. Therefore, we should strengthen the management of non-degree courses, because it is an indispensable link to ensure the training quality of graduate students, especially to improve their scientific research skills and innovation ability. On the College level [1-3], it is imperative to perfect the examination system of non-degree courses.

\section{The Necessity of Perfecting the Examination System of Non-degree Courses}

Perfecting the evaluation system of non-degree courses is conducive to standardizing the teaching behavior of teaching teachers. In general, the examination of "English" and "Politics" in the public compulsory courses in degree courses is organized by the University, and the examination of the basic theory and professional knowledge is often arranged by the College, and the teacher is responsible for the assessment of non-degree courses. From the actual situation at present, the management of non-degree courses in colleges and even disciplines is rare. That is, the assessment of the non - degree course is the responsibility of the teaching teacher, and the teaching effect and the teaching quality are completely related to the teacher's level and sense of responsibility, but some teachers do not pay attention to what graduate students need to learn, and part of the knowledge that they teach is the repetition or continuation of the undergraduate course[4]. Therefore, the examination requirement of non-degree course is relatively loose, and it often cannot play a role of supervision, diagnosis, correct evaluation, and significantly improve the innovative ability of graduate students. At the same time, it cannot promote the cultivation of good style of study and teaching style. Therefore, it is necessary to establish or perfect the evaluation system of non-degree courses for postgraduates.

Perfecting the examination system of Non-degree courses is beneficial to the cultivation of Graduate students' innovative ability. The innovation refers to the existing thinking mode, which is different from the traditional or ordinary thinking. The core of graduate training is the cultivation of scientific research and innovation ability. Most of the non-degree courses are related to the cultivation of innovation ability, but the improvement of innovation ability is affected by many 
factors, including tutors' pressure, schoolmate's pressure, incentives and policy equity [5]. Therefore, perfecting the examination system of non-degree courses is beneficial to the cultivation of graduate students' innovative ability.

Perfecting the examination system of Non-degree courses is beneficial to the correct evaluation of students' academic level. The evaluation of graduate students' academic level during the first grade curriculum study mainly depends on the curriculum assessment, and the result of the curriculum assessment will affect the evaluation of the scholarship. Scholarships are a common way for schools to motivate students to work hard and develop across the board[6]. At present, scholarships are generally awarded to graduate students in China, but the scholarship is hierarchical, and the division of the grade, in the first grade, is mainly based on the results of curriculum assessment. Because of the variety of non-degree courses, different majors and even different specialties choose different courses for graduate students in the same direction. If the assessment is not standardized, it will affect students' course score and the evaluation of student scholarships.

\section{Fully Understand the Content and Function of Non-degree Courses and Make a Good Classification of Courses}

There are 34 elective courses (non-degree courses) offered in our medical college, which are available for medical and related graduate students. According to the requirements of the syllabus, the contents of those courses are briefly analyzed to classify non-degree courses (see table 1).

Table 1. 34 main contents of non-degree courses

\begin{tabular}{|c|c|c|}
\hline No & course title & Course content and requirements \\
\hline 1 & $\begin{array}{l}\text { Medical Specialties } \\
\text { English }\end{array}$ & $\begin{array}{l}\text { To improve the ability of listening, speaking, reading, writing and translating } \\
\text { in medical English for graduate students. }\end{array}$ \\
\hline 2 & $\begin{array}{l}\text { Medical Molecular } \\
\text { Genetics }\end{array}$ & $\begin{array}{l}\text { The perspective of molecular genetics, the relationship between the } \\
\text { occurrence of disease and genes, and gene therapy is carried out through } \\
\text { molecular genetics technology. }\end{array}$ \\
\hline 3 & Molecular Biology & $\begin{array}{l}\text { Molecular biology concerns the molecular basis of biological activity between } \\
\text { biomolecules in the various systems of a cell, including the interactions } \\
\text { between DNA, RNA, and proteins and their biosynthesis, as well as the } \\
\text { regulation of these interactions. }\end{array}$ \\
\hline 4 & $\begin{array}{l}\text { Human Section } \\
\text { Anatomy }\end{array}$ & $\begin{array}{l}\text { Human sectional anatomy is a kind of science which applies sectional } \\
\text { anatomy method to study the morphology and continuous variation of normal } \\
\text { human body. It belongs to the category of applied anatomy and is an } \\
\text { important basic course of medical imaging. }\end{array}$ \\
\hline 5 & Neuroanatomy & $\begin{array}{l}\text { Neuroanatomy is a basic course of normal structure of the human nervous } \\
\text { system, and it is one of the important core content of neuroanatomy in } \\
\text { neuroscience. }\end{array}$ \\
\hline 6 & $\begin{array}{l}\text { Pharmacotherapeuti } \\
\text { cs }\end{array}$ & $\begin{array}{l}\text { The concept and method of drug therapy were introduced systematically, and } \\
\text { the clinical application of modern drugs and the latest drugs were introduced. }\end{array}$ \\
\hline 7 & Cryobiology & $\begin{array}{l}\text { Cryobiology studies the effects of low temperature on organisms and its } \\
\text { application. Its research contents include the mechanism of biological } \\
\text { tolerance to cold environment, the cryopreservation and transplantation of } \\
\text { biological materials and so on. }\end{array}$ \\
\hline 8 & Neurobiology & $\begin{array}{l}\text { Neurobiology introduces the basic theory of neurobiology, including neuronal } \\
\text { communication, nervous system regulation to sensory system, motor system, } \\
\text { advanced function of nervous system, neuroendocrine immune regulation. }\end{array}$ \\
\hline 9 & $\begin{array}{l}\text { Clinical } \\
\text { Epidemiology }\end{array}$ & $\begin{array}{l}\text { Clinical epidemiology involves various disciplines of medical science, and at } \\
\text { the same time, it infiltrates with these disciplines to promote the development } \\
\text { of these disciplines and the development of clinical epidemiology itself. }\end{array}$ \\
\hline 10 & $\begin{array}{l}\text { Medical } \\
\text { Psychology }\end{array}$ & $\begin{array}{l}\text { Medical psychology studies and solves all psychological problems in the } \\
\text { process of health or disease and their mutual transformation, that is, the role } \\
\text { of psychological factors in the etiology, diagnosis, treatment and prevention } \\
\text { of diseases. Such as how to overcome excessive anxiety, how to eliminate } \\
\text { depression, how to establish a harmonious relationship between doctors and } \\
\text { patients. }\end{array}$ \\
\hline 11 & Injury and Repair & The scientific problem of the injury and repair of the nervous system is \\
\hline
\end{tabular}




\begin{tabular}{|c|c|c|}
\hline & of Nervous System & $\begin{array}{l}\text { discussed systematically, including the injury and regeneration of the } \\
\text { peripheral nerve and its research progress. Injury and repair of central nervous } \\
\text { system and its research progress. }\end{array}$ \\
\hline 12 & $\begin{array}{l}\text { Modern Medical } \\
\text { Microbiology }\end{array}$ & $\begin{array}{l}\text { The establishment, improvement and perfection of new molecular biological } \\
\text { techniques and methods have greatly promoted the research of medical } \\
\text { microbiology and the discovery of new pathogenic microorganisms. Many } \\
\text { important breakthroughs have been made in pathogenesis and molecular } \\
\text { diagnosis, and many new theories and concepts have emerged. }\end{array}$ \\
\hline 13 & $\begin{array}{l}\text { Molecular } \\
\text { Pharmacology }\end{array}$ & $\begin{array}{l}\text { Molecular pharmacology is the molecular pharmacological basis of drug } \\
\text { action and its mechanism from the point of view of molecular level and gene } \\
\text { expression, including intracellular, intercellular signal transduction system, } \\
\text { receptor theorv, ion channel, apoptosis, oxvgen free radical and so on. }\end{array}$ \\
\hline 14 & Pathology & $\begin{array}{l}\text { Pathology studies the etiology, pathogenesis and outcome of pathological } \\
\text { changes. }\end{array}$ \\
\hline 15 & $\begin{array}{l}\text { Human Local } \\
\text { Anatomy }\end{array}$ & $\begin{array}{l}\text { The local anatomy of the human body is to study the structure, the } \\
\text { characteristics and the adjacent relation of each part of the human body on the } \\
\text { basis of systematic anatomy. }\end{array}$ \\
\hline 16 & Embryology & $\begin{array}{l}\text { Embryology grasps the development process of human embryonic and normal } \\
\text { human tissue structure, and to understand the genetic regulation during } \\
\text { embryonic development, and to understand the causes, mechanisms and } \\
\text { results of human congenital defects and deformities. }\end{array}$ \\
\hline 17 & $\begin{array}{l}\text { Applied } \\
\text { Immunology }\end{array}$ & $\begin{array}{l}\text { Applied immunology focuses on the introduction of basic immunological } \\
\text { theories and techniques in medical practice and the recent development of } \\
\text { research. }\end{array}$ \\
\hline 18 & Zoonotic Diseases & $\begin{array}{l}\text { Zoonosis describes pathogens, hosts, vectors and foci, foci investigation, and } \\
\text { basic knowledge related to zoonotic infectious diseases. }\end{array}$ \\
\hline 19 & Neurophysiology & $\begin{array}{l}\text { Neurophysiology is a branch of neuroscience that studies the functional } \\
\text { mechanisms of the nervous system including the peripheral nervous system, } \\
\text { the spine, and the brain. It is also a branch of physiology, which focuses } \\
\text { exclusively on the nervous system. }\end{array}$ \\
\hline 20 & $\begin{array}{l}\text { Neurobiology of } \\
\text { Learning and } \\
\text { Memory }\end{array}$ & $\begin{array}{l}\text { The neurobiology of learning and memory introduces the study of learning } \\
\text { and memory from many aspects, including the function of various brain } \\
\text { regions and the regulation system of memory function. }\end{array}$ \\
\hline 21 & $\begin{array}{l}\text { Methods of Medical } \\
\text { Scientific Research } \\
\text { and Paper Writing }\end{array}$ & $\begin{array}{l}\text { Methods of medical scientific research and paper writing introduce the } \\
\text { methodology of medical research and Graduate students are required to } \\
\text { master the basic contents and design principles of the common techniques of } \\
\text { observational research, experimental research and medical investigation and } \\
\text { how to write a good literature review and scientific research papers. }\end{array}$ \\
\hline 22 & $\begin{array}{l}\text { Establishment and } \\
\text { Diagnosis of } \\
\text { Animal Model of } \\
\text { Disease }\end{array}$ & $\begin{array}{l}\text { Establishment and diagnosis of animal model of disease explain in detail the } \\
\text { establishment of animal model and analyze its mechanism, to lay a solid } \\
\text { theoretical foundation for the establishment of animal model in the new } \\
\text { unknown field in the future. }\end{array}$ \\
\hline 23 & $\begin{array}{l}\text { Medical Molecular } \\
\text { Biology } \\
\text { Technology }\end{array}$ & $\begin{array}{l}\text { The basic principles, operating methods and application fields of commonly } \\
\text { used techniques can be understood by medical molecular biology technology } \\
\text { through specific experimental operation. }\end{array}$ \\
\hline 24 & $\begin{array}{l}\text { Medical Statistics } \\
\text { Technology }\end{array}$ & Medical Statistics Technology is the practical part of Medical Statistics. \\
\hline 25 & $\begin{array}{l}\text { Neuroscience } \\
\text { Experimental } \\
\text { Technique }\end{array}$ & $\begin{array}{l}\text { Experimental neuroscience covers new research methods of modern } \\
\text { neuroscience and the basic principle. }\end{array}$ \\
\hline 26 & $\begin{array}{l}\text { DNA Analysis } \\
\text { Technology }\end{array}$ & $\begin{array}{l}\text { Mastering conventional nucleic acid analysis techniques and methods about } \\
\text { the DNA extraction, quantitative amplification, electrophoresis, sequence } \\
\text { analysis and primer design. }\end{array}$ \\
\hline 27 & $\begin{array}{l}\text { Histopathological } \\
\text { Technique }\end{array}$ & $\begin{array}{l}\text { Including conventional histopathology, immunohistochemistry and other } \\
\text { techniques. }\end{array}$ \\
\hline 28 & $\begin{array}{l}\text { Advances in } \\
\text { Oncology }\end{array}$ & $\begin{array}{l}\text { The major progress and prospect of tumor research and its epidemiology, } \\
\text { tumor etiology and pathogenesis, tumor genetics, tumor immunology, tumor } \\
\text { cell biology and tumor molecular biology are introduced. }\end{array}$ \\
\hline 29 & $\begin{array}{l}\text { Advances in } \\
\text { Physiology }\end{array}$ & $\begin{array}{l}\text { Advances in physiology include cytoskeleton, cardiovascular physiology, } \\
\text { digestive physiology, renal physiology and neurophysiology. }\end{array}$ \\
\hline 30 & Advanced & The progress of pharmacology makes graduate students master the most \\
\hline
\end{tabular}




\begin{tabular}{|l|l|l|}
\hline 31 & Pharmacology & $\begin{array}{l}\text { advanced contents of pharmacology and have a new understanding of } \\
\text { organism life activities, especially in clinical pharmacology, } \\
\text { cardio-cerebrovascular pharmacology, tumor pharmacology and so on. }\end{array}$ \\
\hline 32 & $\begin{array}{l}\text { Progress in } \\
\text { Pathophysiology }\end{array}$ & $\begin{array}{l}\text { Training graduate students to clarify the pathogenesis of diseases with new } \\
\text { theories, and lay a good theoretical foundation for future research and } \\
\text { prevention and treatment of diseases }\end{array}$ \\
\hline 33 & $\begin{array}{l}\text { Advances in } \\
\text { Pathogenic Biology } \\
\text { changes) and molecular pathology and and some hot topics such as tumor, } \\
\text { microcirculation disorder, atherosclerosis, metabolic syndrome, organ fibrosis } \\
\text { are introduced. }\end{array}$ \\
\hline 34 & $\begin{array}{l}\text { Progress in pathogenic biology focuses on the progress of its biological } \\
\text { characters, transmission and epidemic laws, clinical testing methods, } \\
\text { prevention and control principles and so on. }\end{array}$ \\
Forensic Medicine & $\begin{array}{l}\text { Progress in forensic science is introduced, including forensic pathology, } \\
\text { forensic clinical science, forensic evidence, forensic toxicology, forensic } \\
\text { psychiatry, traffic medicine, medical disputes, etc. }\end{array}$ \\
\hline
\end{tabular}

Through above analysis and summary, we can see that these courses can be divided into three categories: the professional knowledge of the research direction, the progress of the subject, and the scientific research skills. Different assessment methods should be selected according to different types of courses.

\section{To Determine the Form of Examination According to the Category of Courses}

The examination of academic achievement of professional knowledge courses is based on the score of examination paper. The examination of basic courses in professional direction(see Tab.1:No.1 No.20) refers to the examination of degree courses, in which examination papers account for $70 \% \sim 80 \%$ of the total scores, but the proportion of the new knowledge content is higher.

The examination of the course of Scientific Research skill is based on the skill test. The assessment of scientific research skill courses in Tab.1 No21-27 is mainly based on ordinary skill training, and achievement score, which should account for $60 \%$, is assessed by the results of skill manipulation. Scientific research skills also involve theoretical knowledge and some new concepts, which are tested in written examination[7,8].

The examination of the courses about subject progress is mainly the writing of summary papers. In the subject progression course(see Tab.1:No.28 No.34), graduate students can write a summary of their own research direction to understand the progress of the subject. The requirement of summary paper is to keep from downloading directly on the Internet, and graduate students should be inquired to understand the new progress around the topic selection. The teacher must carefully check the content of the summary, and they can combine with their instructors to evaluate its level, and graduate students in group discussion should use PPT to report to everyone, including students and other teachers, and they can communicate with each other, which plays the role of learning from each other (this part can account for $60 \%$ of the total score). In addition, at least 10 new nouns or new concepts of the progress of the subject are examined in the examination paper (score is $40 \%$ ) in order to promote a more comprehensive understanding of the progress of the subject.

\section{Implementation Measures of Curriculum Examination System}

There must be rules and regulations to perfect the examination system of medical non-degree courses[9]. The system can be carried out by making modules of different kinds of courses, timely training of teachers, supervising of graduate teaching offices or graduate secretaries. Through the implementation of recent years, our college has solved some problem, i.g. that the examination requirements of non-degree courses are not strict and unable to play a learning-oriented role, and that evaluation does not reflect the real level of postgraduate study. At the same time, the innovation consciousness and ability of graduate students are improved, and the objective evaluation can be achieved. 
Of course, the assessment system of postgraduate courses should be constantly improved according to different requirements of the times.

\section{Acknowledgement}

Graduate Education Reform Project of Henan University of Science and Technology. No. 2015YJG-005

\section{References}

[1] F.Z. Zheng, J.X. Lv, J.Liu, The Path Selection on Deepening the Reform of Graduate Cultivation Mechanism in Local Colleges, Education Research.5 (2016) 77-83.

[2] W.H. Zhou, H.Huang, H.F. Fu, J.Q. Liu, Survey of graduate student satisfaction in China, Degree and Graduate Education. 9(2017)41-47.

[3] P.W.Wang, Thoughts on Optimizing the Tertiary Management of Graduate Education in Our University, Journal of Guangdong Medical College. 26(2008) 319-320.

[4] F.L.Qin Wang H, C.X.Hu, Problems in Graduates Curricula Teaching and Countermeasures, Journal of Huazhong Agricultural University (Social Sciences Edition). 6(2007)148-150.

[5] X.R. Gao, Q. Wan, Y.Chen, The Factors Affecting the Improvement of Postgraduates' Research Ability and Their Mechanism, Jourmal of Higher Education Managemrnt. 9(2015) 114-117.

[6] G.Xu, H.B.Ma, Several problems on graduate studies scholarship in the implementation process, Degree and Graduate Education. 12(2015)27-32.

[7] R.L.Wu, J.Z.Wang. Research-based Teaching and the cultivation of Graduate students'Innovative ability, Degree and Graduate Education. 3(2013)10-15.

[8] J.Y. Tao, S.Q. Kuang, D.X.Yang, Exploration on Postgraduate Practice Teaching System with Innovation-oriented, Research and Exploration in Laboratory, 32(2013)317-320.

[9] L.H.Ma, Exploration and Practice of Postgraduate course Construction in Provincial Colleges and Universities, Degree and Graduate Education. 10(2017)24-28. 